УДК 94(47)+167.5

24.00.00 Культурология

СОЦИОКУЛЬТУРНЫЕ ПРОЕКТЫ ДМ. МЕРЕЖКОВСКОГО И И. ИЛЬИНА

Митина Наталья Георгиевна

д. ф. н., доцент,

SPIN-код: 7196-2178, AuthorID: 385181

Дальневосточный государственный институт

искусств, г. Владивосток, Россия

Статья посвящена утопическим проектам Дм. Мережковского «Третье Царство» и И. Ильина «Русская идея». Методологическую основу исследования составляет феноменологическая концепция «жизненного мира». Утопия рассматривается в качестве явления социокультурной действительности, включающего в себя характерные черты той цивилизации, на базе которой она формируется. Проекты направлены к синтезу религии и культуры через духовное возрождение человека. Выявлена специфика утопий - духовность и метафизичность, что позволило определить их как социокультурные проекты

Ключевые слова: УТОПИЯ, СОЦИОКУЛЬТУРНЫЙ ПРОЕКТ, «ЖИЗНЕННЫЙ МИР», ДУХОВНОСТЬ, ЛЮБОВЬ, ЦАРСТВО БОЖЬЕ

Doi: 10.21515/1990-4665-129-013
UDC 94(47)+167.5

Cultural sciences

\section{SOCIOCULTURAL PROJECTS OF DM. MEREZHKOVSKY AND I. ILYIN}

Mitina Natalia Georgievna

Doctor in Philosophy, Associate professor

SPIN- code: 7196-2178, AuthorID: 385181

Far Eastern State Institute of Arts, Vladivostok, Russia

The article is devoted to utopian projects of Dm. Merezhkovsky «The Third Kingdom» and I. Ilyin «The Russian Idea». The methodological basis of the study is a phenomenological concept of «life-world». The utopia considered in the present paper as a phenomenon of sociocultural reality, including the characteristic features of the civilization on the basis of which it is formed. Projects directed to the synthesis of religion and culture through spiritual rebirth of man. The specificity of utopias is revealed - spirituality and metaphysics, which allowed to define them as sociocultural projects

Keywords: UTOPIA, SOCIOCULTURAL PROJECT, «LIFE-WORLD», SPIRITUALITY, LOVE, THE KINGDOM OF GOD

Изучение русской философской утопии позволит выявить специфику проектов и определить базовые особенности русской культуры. Как социокультурное явление, утопия представляет интерес в стремлении человека к поиску новых лучших форм общественного устройства. Утопия конструирует возможное будущее, используя накопленный опыт, и выступает, как культурный феномен, своеобразным мостиком между временными характеристиками «жизненного мира». Это обусловило неослабевающий интерес к утопии и свидетельствует об актуальности темы исследования.

Утопия, как продукт нашей повседневной жизни, включает в себя особенности культурных и социальных отношений конкретной человеческой общности. Специфика русской утопии определяется 
особенностями сознания русских, спецификой цивилизационного развития. На утопичность русской ментальности указывали разные философы, подчеркивая «неотмирность», мечтательность русских, стремление к поиску абсолютного добра [16], [1, с. 52-53], [25, с. 104]. Идеалом было Царство Божие, к которому сознание русского человека, указывает В.Н. Муравьев, шло «через Церковь и Государство, сливая их в образе великой, сначала русской, затем вселенской теократии» [24, с. 58]. Отличительной чертой русской утопии является ее религиозность и нравственная сущность, которая коренится в особенностях русского самосознания, в приоритете духа над формой. Утопия, таким образом, выражает христианский идеал Царства Божьего, но как земного, созидаемого людьми без Бога, где реализуется ответственность человека за историю; вера в свою провиденциальную миссию: указать людям путь правильного жизнеустройства, спасти человечество [23, с. 49-63]. Проекты Дм. Мережковского и И. Ильина представляют собой наиболее яркие примеры специфики русской утопии. Они вобрали в себя особенности русского «жизненного мира» и уделяют значительное внимание духовному совершенствованию.

Остановимся на проекте Дмитрия Мережковского. Концепция изложена в трех произведениях философа: «Тайна трех. Египет Вавилон», «Тайна Запада. Атлантида - Европа» и «Иисус Неизвестный», где философ раскрывает свое представление о будущем человечества. Проект отражает специфику эпохи Серебряного века и впитал в себя ее ценностные характеристики - телесность, духовность, соборность.

Для Дм. Мережковского конечной целью его утопии Царство Божье, где он предполагает реализовать свои идеи об эволюции христианства, создании всемирной церкви, гармонии природы и социума и раскрытие тайны пола. Философ пытается соединить два противоположных полюса христианской святости - «святость Духа и 
святость Плоти» [22, с. 147]. Он определяет человека как «религиозное животное» $[17$, с. 1], совмещая, таким образом, духовное и природное телесное начало, подчеркивая двойственную природу человека. Основная мысль, которая выделена философом и на которой строится его проект духовная плоть, единение Духа и Плоти. Следовательно, духовность выступает ключевым элементом концепции Дм. Мережковского.

Проект Ивана Ильина, определенный им как «Русская идея», также строится на духовных основах, но ограничен рамками России и не уделяет особое внимание проблеме телесности. Концепция оформилась в работе «Путь духовного обновления» и в двухтомнике «Наши задачи», созданных в эмиграции. Основные положения были им сформулированы в работе «О Русской идее», где он отмечает национальный характер этой идеи, выражающей особенности национальной общности. Философ указывает, что Русская идея выделяет особенности русского народа, что «русскому народу уже присуще», и определяет «нашу историческую задачу и наш духовный путь» [12, с. 312].

И.А. Ильин выделяет специфику России и ее задачи, которые философ разделяет на первичные силы культуры - сердце, созерцание, свобода (определяют и ведут) и вторичные силы культуры - воля, форма, организация (исходят из первичных). По мнению философа это разделение позволит достигнуть цели, свидетельствует о самобытности русской культуры [12, с. 318-319]. Для И. Ильина, сформулированная им «Русская идея» заключается в свободной христианизации культуры через созерцание сердцем, духом сердечного созерцания [5, с. 617]. Это «идея православного христианства», заложенная в основе русской цивилизации, в самой структуре творческого акта [12, с. 321], [8, с. 2]. По мнению философа России необходимо покаяние и очищение, чтобы восстановить «живую христианскую совесть» [9, с. 397]. Таким образом, проект «Русская идея» строится на специфических особенностях России, 
ее духовных истоках, на основе христианских ценностей и национальных традиций.

Он формулирует творческую идею как «свободную христианизацию всей культуры», где национальный характер воспитывается на основе «свободного созерцания сердцем и созерцания совестью». По мнению И. Ильина Царство Божие начинается реально на этом духовном уровне и «Святая Русь» так же реальна и представляет собой святую народную энтелехию, которая задает смысл бытию [8, с. 2]. Данная идея, отмечает Ю.Т. Лисица, является имманентной первоосновой русского бытия и она реальна $[15$, с. 5].

Идея «Святой Руси» находится в основе проекта философа и является основой православного воззрения. «Царство Божие» для И. Ильина это ткань особого измерения - «живая божественная ткань, к которой человек должен прилепиться душой и телом», «целостный духовныцй мир», где, объединенные молитвой, трудятся христиане «в духе Христа ради преображения человека и природы» [5, с. 464-465]. И в процессе реализации этой идеи (строительства христианской культуры) Церковь остается «творческой хранительницей, живым и авторитетным источником того христианского духа, из которого народ только и может создавать христианскую культуру на земле», но не принимает непосредственного участия, так как «земная культура творится не государством и не Церковью, а народом» [6, с. 510-524]. Следовательно, культура является главной составляющей творческой идеи.

Культура это создание души и духа и христианство вносит во всю культуру «дух христианской предметности», указывает И. Ильин. Творить культуру может только человек, раскрывший «глубину своего сердияа для Христова Духа», и из него обратившийся «к созерцающчему восприятию Бога и Божьего мира, ...к свободным и ответственным волевым деяниям в плане Божьего Дела на земле». Это вводит 
христианский дух во все деяния человека и предоставить ему творить «живую христианскую культуру». Однако для этого надо «принять Божий мир и зажить им и в нем» [6, с. 493-500]. У философа воедино сливаются культура и христианство и приобретают особое значение в возрождении новой России.

Все составляющие проекта И. Ильина (политическую, социальную, экономическую организацию будущего общества) пронизывает духовный аспект. Философ подчеркивает: «право и государство возникают из внутреннего, духовного мира человека, создаются именно для духа и ради духа и осуществляются через посредство правосознания». Основу государства и политики составляет духовная солидарность, всеобщая солидарность и взаимность граждан. В этом случае мы можем говорить о социальном государстве - государстве всеобщей солидарности и гражданского братства, выполняющем свое духовное и христианское призвание и воспитывающем своих граждан «в духе христианской политики» [7, с. 228-245].

Анализируя вопросы веры, философ подчеркивает связь в человеке материи и духа: задача духа - набрать силу и подчинить тело, которое станет носителем бессмертного духа. Духовный мир одновременно находится над материальным миром и внутри него, философ обозначает его как Царство Божие. Данное мировоззрение есть основа народной веры, которая проявляется во всех областях русской культуры. Вера русского народа исторически возникла и будет укрепляться вместе с «историческим становлением русского народа», отмечает философ [5, с. 425-466]. И. Ильин называет веру «первичной силой человеческой жизни». Источником веры, религии и всей духовной культуры, по мнению философа, является внутренний (нечувственный) опыт человека, через него человек «сообщуатся с божественной стихией мира и входит в живое соприкосновение с Богом», он делает человека человеком, духовной 
личностью, а источником духовного опыта и религиозной веры выступает любовь [7, с. 19-51]. Философ отмечает необходимость цельной веры, где разум, сердце, воля и созерцание должны соединиться в единый поток [13]. Таким образом, духовные аспекты бытия непосредственно обусловили и определили для философа веру и религию русского человека.

Наоборот, Дм. Мережковский считает необходимой эволюцию христианства, с которой он связывает решение проблемы духа и плоти. Его религия «Третьего Завета» и должна решить эту проблему, примирить души и тело. По мнению М.А. Воскресенской: «Мыслитель видел в христианстве чрезмерность духа, а в эллинизме - чрезмерность плоти... Его идеал - одухотворение плоти, синтез христианства и язычества, снимающий противоречие между ними» [2, с. 127].

Философ считает, что сходство христианства и язычества в разделении и противоречии духа и плоти, что и стало причиной гибели дохристианского и станет причиной гибели христианского мира. Решение по его мнению в одухотворении Плоти. Он противопоставляет «высшую святыню плоти» христианской «бестелесности» [2]. В своей концепции Дм. Мережковский пытается объединить язычество и христианство, где заключается возможность примирения противоречий, новый синтез. Для него Дух и Плоть являются равноценными и равносвятыми, в этом заключена главная цель его проекта. Через гармонию Духа и Плоти, считает философ, мы достигнем гармонии внутри социума.

Дм. Мережковский распространяет свою концепцию Третьего Завета и на свое учение о всемирной церкви. Он считает, что соединение Западной и Восточной церкви (церквей Петра, Павла и Иоанна) повлечет к созданию единой Церкви Святой Софии, Премудрости Божьей, где произойдет единение Духа и Плоти [22, с. 154].

В отличие от Дм. Мережковского, И. Ильин противопоставляет православие и католицизм и считает, что для России православная вера 
единственно верная, так как она единственная имеет такие ценности, как «живая совесть, искренняя молитва и личное «добровольчество»» [11]. Роль церкви заключается в «оцерковлении» (что означает «христианское одухотворение человеческого сердца»), церковь, одухотворяя сердца людей, выпускает их в мир для того, чтобы они могли одухотворить мир [14, с. 402]. В этом процессе велика и роль духовного наставника пастыря, который должен быть живым источником «молитвы, любви $и$ христианской совести» [7, с. 379-381]. Церковь, подчеркивает Ильин, «не объемлет всю жизнь человека и не «регулирует» всю культуру человечества: ни в науке, ни в искусстве, ни в политике, ни в хозяйстве... Церковь не призвана к светской власти» [6, с. 510-517]. Таким образом, роль Церкви, как организации, учить, наставлять благодатной мудрости, но не вмешиваться в мирские дела.

Особое значение для И. Ильина имеет чувство любви, которой отводится главная роль в формировании духовного опыта, она выступает источником духовности. Он разделяет любовь на «любовь инстинкта и любовь духа», где любовь инстинкта определяется тем, что субъективно приятно, доставляет личное удовольствие, в то время как любовь духовная исходит из качества, достоинства и совершенства, это «голод души по Божественному». Духовная любовь источник веры, путь к Богу, она дает человеку свободу. Для философа эти два типа не исключают один другого, более того в случае их сочетания «чувственная любовь становится верным и точнымм знаком духовной близости и духовной любви» [7, с. 5470]. Любовь есть основа семьи подчеркивает философ, а семья для него выступает «первичным лоном человеческой культуры» [7, с. 137-138].

Философ не останавливается подробно на вопросах пола и телесности, но рассматривает отдельные аспекты проблемы, анализируя специфику России. В работе «О вечно-женственном и вечномужественном в русской душе» он отмечает, что вечно-женственное и 
вечно-мужественное «в сущности своей всегда равнозначны», но каждым отдельным человеком и каждым народом они воспринимаются по-своему, они «переплетены, различны и соединены в женской душе и в мужской душе». Характеристика женского и мужского у Ильина соответствует концепции античных философ: «Женское бытие - это состояние и судьба; мужское бытие - это самоопределение, акт...». И утрата этой сущности губительно как для женщины, так и для мужчины: «В каждой женщине, не утратившей вечно-женственного, в каком-то уголке поет ангел, в каждом муже, не преступившем и не исказившем грань вечно-мужественного, говорит и неистовствует титан». России, по мнению Ильина, «вечноженственное дано, а вечно-мужественное - задано». Два начала «взаимно дополняют, взаимоограждают, взаимооплодотворяют» друг друга и нарушение этой гармонии ведет к распаду, которое философ связывает с кризисом современной культуры [4, с. 411-429].

Анализируя исторический путь России, он приходит к выводу, что мужчина «хочет видеть в женщине не просто возлюбленную, не просто приятную спутницу жизни, он ищет твердый характер, ему нужен ангелхранитель». Женщина в обществе, указывает Ильин, является источником силы и вдохновения для мужчины и истинным духовным материнским лоном для детей [5, с. 494-495]. Следовательно, в определении роли женщины он стоит на патриархатной позиции, что характерно для русской философии в рассматриваемый период.

Философ уделяет внимание значению телесного бытия для человека: «Мы не можем и не должны презирать или тем более «отвергать» наше тело: ведь оно вводит нас в вещественный мир, полный разума и красоты, оно открывает нам все чудеса Богосозданной твари, всю значительность, и чистоту, и величие материальной природы. Тело есть необходимое и естественное орудие нашего приобщения к Божьему миру, нашего участия в нем...» [7, с. 866-867]. Тело выступает как «носитель духа», его 
«инструмент», «живейший орган и символ». Тело выражает духовность, аккумулированную в человеке, отвечает на духовный заряд, «поддается живому динамическому воздействию». Это связь с Богом, «отождествление», подчеркивает И. Ильин [5, с. 455-456]. От Бога и природы человеку дан «индивидуальный способ», который включает телесное существование, душевную жизнь и духовное бытие. Философ подчеркивает: «Всякая теория и всякая педагогика и политика, которые с ним не считаются, вступают на ложный и обреченный путь». Индивидуальный способ существования, подчеркивает важность личностных характеристик человека, его творческого начала, что представляется философу необходимым для существования общества и культуры [7, с. 255]. В этом большую роль играет чувство любви, которая «индивидуализирует» человека, делает его личностью [10, с. 565]. Таким образом, в концепции И. Ильина человек рассматривается как телеснодуховно-душевная индивидуальность и его проект новой России строится исходя из этих особенностей.

В концепции Дм. Мережковского женское начало приобретает особую роль: «... Перворелигию всего человечества - религию Матери Сын освящает, Новый Завет соединяет с Ветхим - только здесь... завершается догмат о Троице: Отец, Сын и Матерь Дух» [18, с. 67]. По мнению философа религия Трех разрешит противоречие, плоть и дух соединятся в Любви, что и приведет в Царство Божие. Таким образом, пол и любовь в концепции Дм. Мережковского выступают системообразующими элементами и приобретают религиозное значение.

Любовь соединяет противоположности, ей придается особое значение как в проекте И. Ильина, как указывалось выше, так и в утопии Дм. Мережковского. Выделяя типы любви (плотскую и духовноплотскую), Дм. Мережковский особое значение придает духовно-плотской любви, которая, по его мнению, способна победить смерть [18, с. 510-511]. 
Он подчеркивает: «Только эта последняя любовь есть в то же время последняя свобода; только эта последняя любовь - абсолютное утверждение других в Боге - есть в то же время последняя свобода утверждение себя в Боге»[19]. Следовательно, каждый тип играет свою роль и выполняет свои задачи, но только в духовно-плотской любви открывается богочеловеческое единство, эта ювенильная любовь способна преодолеть раскол пола, восстановить личность.

По мнению философа, окончательное решение проблемы пола заключается в восстановлении половой целостности, божественной Двуполости - образа муже-женщины, андрогина: «природа сочетала мужское с женским в прекраснейшую гармонию и первичное установила согласье с помощью противоположностей; каждый атом заключает в себе два полюса одной силы... Этой физической полярности атомов-солнц соответствует физиологическая двуполость эмбрионов... Может быть, это и есть наш «первородный грех» - то, за что миг рождения, молния времени, рассекает нас пополам, на мужчин и женщин» [20, с. 253]. Он считает, что восстановление божественной двуполости победит смерть: «Когда два будут Одно, и мужское будет женским, и не будет ни мужского, ни женского, придет царствие Божие» [21, с. 536]. Тайной воскресения для него является тайна Богосупружества - двое одна плоть, восстановление гармонии. Таким образом, в концепции философа соединяются три взаимосвязанных и взаимозависимых компонента - Пол, Личность и Общество. Гармонизация социума заключается в реализации проекта Третьего царства, который связан с восстановление андрогинного образа человека при помощи духовно-плотской ювенильной любви.

Таким образом, в проекте Дм. Мережковского уделяется внимание духовному совершенствованию человека и необходимости переоценки ценностей для восстановления гармонии социума и природы. Данная утопия стремится воплотить идеал духовного возрождения с помощью 
синтеза религии и культуры, ее цель - достижение Царства Божьего, где произойдет единение Духа и Плоти. Утопический проект И. Ильина так же охватывает различные аспекты бытия, философу продемонстрировал важность духовного и творческого начала в развитии русской цивилизации и определил путь ее обновления - восстановление духовных основ, возвращение к христианской культуре.

Данные утопии ярко демонстрируют желание своих авторов реализовать проект Царства Божия через Церковь и Государство, но И. Ильин это делает в рамках России, а Дм. Мережковский - всего мира. Философы создали утопии, связанные единством «жизненного мира» с проектами русской классической утопии второй половины XIX - середины XX вв. Оба проекта построены на духовной основе, являются метафизическими, что позволило определить их как социокультурные проекты, впитавшие в себя специфику культурных и социальных отношений русской цивилизации.

\section{Литература}

1. Бердяев Н. Миросозерцание Достоевского. - [Электронный ресурс]. Адрес доступа: http://www.magister.msk.ru/library/philos/berdyaev / berdn008.htm. - 76 c.

2. Воскресенская М.А. Символизм как мировидение Серебряного века: Социокультурные факторы формирования общественного сознания российской культурной элиты рубежа XIX - XX веков / Науч. ред. А. Н. Жервина. - М.: Логос, 2005. - $236 \mathrm{c}$.

3. Ильин И.А. Из книги «Сущность и особенность русской культуры» (1944). Воля к совершенству // Пространство и Время. - 2010. - № 2. - С. 222-226.

4. Ильин И.А. О вечно-женственном и вечно-мужественном в русской душе // Сущность и своеобразие русской культуры / Сост., подгот. текста, вступ. ст., коммент. Ю.Т. Лисицы. - М.: Русская книга - XXI век, 2007. - С. 409 - 434.

5. Ильин И.А. О русской культуре. Сущность и своеобразие русской культуры. Три размышления // Собрание сочинений: В 10 т. / Сост. и коммент. Ю. Т. Лисицы; Худож. JI. Ф. Шканов. - Т. 6. - Кн. II. - М.: Русская книга, 1998. - С. 373 - 620.

6. Ильин И.А. Основы христианской культуры // Путь духовного обновления / Сост., авт. предисл., отв. ред. О. А. Платонов. - М.: Институт русской цивилизации, 2011. - С. $476-526$.

7. Ильин И. А. Путь духовного обновления / Сост., авт. предисл., отв. ред. О. А. Платонов. - М.: Институт русской цивилизации, 2011. - 1216 с.

8. Ильин И.А. Творческая идея России // Собрание сочинений: В 10 т. /Сост. и коммент. Ю. Т. Лисицы; Худож. JI. Ф. Шканов. - Т. 6. - Кн. II. - М.: Русская книга, 
1998. - С. 613 - 620. - [Электронный ресурс]. Адрес доступа: http://vikent.ru/enc/3480/ (дата обращения: 17.02.16). - 4 с.

9. Профессор И.А. Ильин. О возрождении России // Наши задачи. Статьи 1948-1954 гг. - Том II. - Париж: Издание Русского Обще-Воинского Союза, 1956. - С. $394-398$.

10. Профессор И.А. Ильин. О моральном обновлении человечества // Наши задачи. Статьи 1948-1954 гг. - Том II. - Париж: Издание Русского Обще-Воинского Союза, 1956. - С. 559 - 566.

11. Профессор И.А. Ильин. О православии и католичестве // Наши задачи. Статьи 1948-1954 гг. - Том I. - Париж: Издание Русского Обще-Воинского Союза, 1956. - C. $286-295$.

12. Профессор И.А. Ильин. О Русской идее // Наши задачи. Статьи 1948-1954 гг. - Том I. - Париж: Издание Русского Обще-Воинского Союза, 1956. - С. 312 - 321.

13. Профессор И.А. Ильин. Чего мы ожидаем от наших пастырей? // Наши задачи. Статьи 1948-1954 гг. - Том I. - Париж: Издание Русского Обще-Воинского Союза, 1956. - С. $216-219$.

14. Профессор И.А. Ильин. Церковь и жизнь // Наши задачи. Статьи 1948-1954 гг. - Том II. - Париж: Издание Русского Обще-Воинского Союза, 1956. - С. 398 - 403.

15. Лисица Ю.Т. Идеи идеалы русской культуры // Ильин И.А. Сущность и своеобразие русской культуры / Сост., подгот. текста, вступ. ст., коммент. Ю.Т. Лисицы. - М.: Русская книга - XXI век, 2007. - С. 3 - 12.

16. Лосский Н.О. Характер русского народа. - М.: Издательский Совет Русской Православной Церкви, Издательство «ДАРЪ», 2005. - 336 с.

17. Мережковский Д.С. Высказывания. - Страница 1. - [Электронный ресурс]. Адрес доступа: http://losev-library.ru/index.php?pid =2120 (дата обращения: 01.09.2008). $-1 \mathrm{c}$.

18. Мережковский Д. С. Иисус неизвестный. - М.: «Республика», 1996. - 687 с.

19. Мережковский Д.С. Меч. IX - X. // Публицистика. Не мир, но меч [Электронный ресурс] / Д.С. Мережковский // Полное энциклопедическое собрание сочинений. - Серия: Электронная библиотека. - М. : ИДДК, 2007. - 1 электрон. опт. диск (CD-ROM). $671 \mathrm{c}$.

20. Мережковский Д.С. Тайна Запада. Атлантида - Европа. - М.: Эксмо, 2007. -

21. Мережковский Д.С. Тайна трех. Египет - Вавилон. - М.: Изд-во Эксмо, 2005. $-560 \mathrm{c}$.

22. Мережковский Д.С. Л. Толстой и Достоевский // Л. Толстой и Достоевский. Вечные спутники. - М.: Республика, 1995. - С. 5 - 350.

23. Митина Н.Г. Дискурс будущего в русской социокультурной утопии [Электронный ресурс]: дис. ... д-ра филос. наук: 09.00.13. - Владивосток, 2014. - 334 с.

24. Муравьев В.Н. Неведомая Россия. Рев племени // Овладение временем. - М.: РОССПЭН, 1998. - С. $52-72$.

25. Шубарт В. Европа и душа Востока. - М.: «Русская идея», 2000. - 446 с.

\section{References}

1. Berdjaev N. Mirosozercanie Dostoevskogo. - [Jelektronnyj resurs]. Adres dostupa: http://www.magister.msk.ru/library/philos/berdyaev / berdn008.htm. - 76 s.

2. Voskresenskaja M.A. Simvolizm kak mirovidenie Serebrjanogo veka: Sociokul'turnye faktory formirovanija obshhestvennogo soznanija rossijskoj kul'turnoj jelity rubezha XIX - XX vekov / Nauch. red. A. N. Zhervina. - M.: Logos, 2005. - 236 s. 
3. Il'in I.A. Iz knigi «Sushhnost' i osobennost' russkoj kul'tury» (1944). Volja k sovershenstvu // Prostranstvo i Vremja. - 2010. - № 2. - S. 222-226.

4. Il'in I.A. O vechno-zhenstvennom i vechno-muzhestvennom v russkoj dushe // Sushhnost' i svoeobrazie russkoj kul'tury / Sost., podgot. teksta, vstup. st., komment. Ju.T. Lisicy. - M.: Russkaja kniga - XXI vek, 2007. - S. 409 - 434.

5. Il'in I.A. O russkoj kul'ture. Sushhnost' i svoeobrazie russkoj kul'tury. Tri razmyshlenija // Sobranie sochinenij: V 10 t. / Sost. i komment. Ju. T. Lisicy; Hudozh. JI. F. Shkanov. - T. 6. - Kn. II. - M.: Russkaja kniga, 1998. - S. 373 - 620.

6. Il'in I.A. Osnovy hristianskoj kul'tury // Put' duhovnogo obnovlenija / Sost., avt. predisl., otv. red. O. A. Platonov. - M.: Institut russkoj civilizacii, 2011. - S. 476 - 526.

7. Il'in I. A. Put' duhovnogo obnovlenija / Sost., avt. predisl., otv. red. O. A. Platonov. - M.: Institut russkoj civilizacii, 2011. - $1216 \mathrm{s.}$

8. Il'in I.A. Tvorcheskaja ideja Rossii // Sobranie sochinenij: V 10 t. /Sost. i komment. Ju. T. Lisicy; Hudozh. JI. F. Shkanov. - T. 6. - Kn. II. - M.: Russkaja kniga, 1998. - S. 613 - 620. - [Jelektronnyj resurs]. Adres dostup: http://vikent.ru/enc/3480/ (data obrashhenija: 17.02.16). $-4 \mathrm{~s}$.

9. Professor I.A. Il'in. O vozrozhdenii Rossii // Nashi zadachi. Stat'i 1948-1954 gg. Tom II. - Parizh: Izdanie Russkogo Obshhe-Voinskogo Sojuza, 1956. - S. 394 - 398.

10. Professor I.A. Il'in. O moral'nom obnovlenii chelovechestva // Nashi zadachi. Stat'i 1948-1954 gg. - Tom II. - Parizh: Izdanie Russkogo Obshhe-Voinskogo Sojuza, 1956. - S. 559 - 566.

11. Professor I.A. Il'in. O pravoslavii i katolichestve // Nashi zadachi. Stat'i 19481954 gg. - Tom I. - Parizh: Izdanie Russkogo Obshhe-Voinskogo Sojuza, 1956. - S. 286 295.

12. Professor I.A. Il'in. O Russkoj idee // Nashi zadachi. Stat'i 1948-1954 gg. - Tom I. - Parizh: Izdanie Russkogo Obshhe-Voinskogo Sojuza, 1956. - S. 312 - 321.

13. Professor I.A. Il'in. Chego my ozhidaem ot nashih pastyrej? // Nashi zadachi. Stat'i 1948-1954 gg. - Tom I. - Parizh: Izdanie Russkogo Obshhe-Voinskogo Sojuza, 1956. S. $216-219$.

14. Professor I.A. Il'in. Cerkov' i zhizn' // Nashi zadachi. Stat'i 1948-1954 gg. - Tom II. - Parizh: Izdanie Russkogo Obshhe-Voinskogo Sojuza, 1956. - S. 398 - 403.

15. Lisica Ju.T. Idei idealy russkoj kul'tury // Il'in I.A. Sushhnost' i svoeobrazie russkoj kul'tury / Sost., podgot. teksta, vstup. st., komment. Ju.T. Lisicy. - M.: Russkaja kniga - XXI vek, 2007. - S. 3 - 12.

16. Losskij N.O. Harakter russkogo naroda. - M.: Izdatel'skij Sovet Russkoj Pravoslavnoj Cerkvi, Izdatel'stvo «DAR», 2005. - 336 s.

17. Merezhkovskij D.S. Vyskazyvanija. - Stranica 1. - [Jelektronnyj resurs]. Adres dostupa: http://losev-library.ru/index.php?pid =2120 (data obrashhenija: 01.09.2008). $-1 \mathrm{~s}$.

18. Merezhkovskij D. S. Iisus neizvestnyj. - M.: «Respublika», 1996. -687 s.

19. Merezhkovskij D.S. Mech. IX - X. // Publicistika. Ne mir, no mech [Jelektronnyj resurs] / D.S. Merezhkovskij // Polnoe jenciklopedicheskoe sobranie sochinenij. - Serija: Jelektronnaja biblioteka. - M.: IDDK, 2007. - 1 jelektron. opt. disk (CD-ROM).

20. Merezhkovskij D.S. Tajna Zapada. Atlantida - Evropa. - M.: Jeksmo, 2007. - 671 S. $560 \mathrm{~s}$

21. Merezhkovskij D.S. Tajna treh. Egipet - Vavilon. - M.: Izd-vo Jeksmo, 2005. -

22. Merezhkovskij D.S. L. Tolstoj i Dostoevskij // L. Tolstoj i Dostoevskij. Vechnye sputniki. - M.: Respublika, 1995. - S. 5 - 350.

23. Mitina N.G. Diskurs budushhego v russkoj sociokul'turnoj utopii [Jelektronnyj resurs]: dis. ... d-ra filos. nauk: 09.00.13. - Vladivostok, 2014. - 334 s. 
24. Murav'ev V.N. Nevedomaja Rossija. Rev plemeni // Ovladenie vremenem. - M.: ROSSPJeN, 1998. - S. $52-72$.

25. Shubart V. Evropa i dusha Vostoka. - M.: «Russkaja ideja», 2000. - 446 s. 